\title{
NOTES ON THE BIONOMICS OF THE TUBE- BUILDING AMPHIPOD, LEPTOCHEIRUS PILOSUS ZADDACH
}

\author{
By C. B. Goodhart
}

Gonville and Caius College, Cambridge

(Text-figs. I-3)

\begin{tabular}{|c|c|c|c|c|c|c|c|c|c|c|c|}
\hline \multicolumn{12}{|c|}{ CONTENTS } \\
\hline Introduction & & . & . & . & . & . & . & & & . & $3 I I$ \\
\hline The cement & gland & & . & . & . & . & . & . & . & . & 312 \\
\hline Construction & of th & he tul & & . & . & . & . & . & . & . & 313 \\
\hline Position in tl & e tuk & & . & . & . & . & . & . & . & . & 317 \\
\hline Feeding habi & & & . & . & . & . & . & . & . & . & 318 \\
\hline Breeding hat & its ar & ad lif & & & . & . & . & . & . & & $32 \mathrm{I}$ \\
\hline Conclusion & . & . & . & . & & . & . & & & . & 322 \\
\hline Summary & . & . & . & . & . & . & . & . & . & . & 323 \\
\hline References & . & . & . & . & & . & . & . & . & . & 324 \\
\hline
\end{tabular}

\section{INTRODUCTION}

It is well known that amphipods belonging to several different families live habitually in nests or burrows built for this purpose. These tubicolous species are all more or less adapted for the construction of tubes, while many have other modifications associated with their feeding habits, which are necessarily rather different from those of the more numerous free swimming species. An inquiry into the natural history of the small brackish water amphipod, Leptocheirus pilosus Zaddach, disclosed habits that appear somewhat different from those of the other tubicolous species which have been investigated.

$L$. pilosus has been recorded from brackish or almost fresh water on most of the coasts of Europe, from the Baltic to the Mediterranean. In England the records are sparse, but the species seems fairly widespread, and probably occurs in most of the estuaries of the British Isles. The whole of the material used in this work was obtained from a sluice pond at Keyhaven near Lymington in Hampshire, which, in September, contained about one-quarter sea water, but which is probably subject to considerable variations. The animal was abundant here, together with the other characteristic brackish water amphipods, Corophium insidiosum Crawford and Gammarus zaddachi Sexton. It can be kept in the laboratory without much difficulty in shallow dishes containing the alga Chondrus crispus, among which it lives, together with a quantity of the detritus from the bottom of the pond. The water in these dishes should not be more than 2 or 3 in. in depth, and overcrowding must be avoided, as the amphipod will only live in well oxygenated water. 
Leptocheirus belongs to the family Photidae, the majority of which are known to be tubicolous. It is rather smaller than most of the Amphipoda, rarely exceeding $4 \mathrm{~mm}$. in length, while the characteristic lateral compression of the body has, to a considerable extent, been lost. In a fully grown male the distance between the lower edges of the coxal plates of each side of the body is equal to about a third of the length from head to telson.

When alive the animal is a dark reddish brown on top, while ventrally it is much paler. This colour is due to the presence of a number of large much-branched pigment cells, dark red in colour, situated on the back, the mesosome, and the upper part of the coxal plates. They are fewer on the metasome and urosome, and entirely absent from the appendages, with the exception of the posterior margin of the basal (Ist) joints of the last three pairs of peraeopods. These pigment spots are of the type observed by Holmes (I9OI) in Amphithöe longimana Smith, except that the large pale green cells found in this animal are not present in Leptocheirus pilosus. Besides the pigment cells the animal is coloured by the gut, which is usually black and opaque; by the gonads, especially prominent in the female, which are yellow or orange in colour; by the eggs, which are dark brown while being carried in the brood pouch; and, in most, by an opaque white patch, which appears to be in the chitin, extending from behind the head to the third or fourth segment of the mesosome. The eye is black.

There is a certain amount of variation in colour among individuals, and they appear to possess the power of altering their colour slightly, but to an even smaller extent than does Amphithöe longimana. Several animals were kept in a dish containing part of the thallus of Ulva in clear water. After three days the pigment cells were still expanded, although since the gut was empty, the animals were rather paler than at the beginning of the experiment. On the fourth day they all died, probably from lack of suitable food. After death, and particularly in specimens preserved in alcohol, the colour fades considerably, though the pigment cells appear to remain uncontracted. When out of water the body, and especially the coxal plates, has a red and green iridescence. The chitin of the exoskeleton is hydrofuge, and an animal which has become caught in the surface film is unable to break it. This is perhaps due to the mucus secreted from the dermal glands on the coxal plates.

Morphologically the whole genus has been described in detail by Sexton (I9II).

\section{The Cement Glands}

The presence of glandular tissue in the first and second pairs of peraeopods ${ }^{\star}$ of many amphipods was first recognized by Smith (1874), who suggested that they secreted the cement used in tube building. He also noticed that they communicated to the exterior through a pore at or near the tip of the

\footnotetext{
* In this paper the nomenclature of Stebbing (1906) is followed, and the first pair of peraeopods is accordingly that immediately posterior to the gnathopods, and attached to the third free segment of the body.
} 
claw. Calman (I909) states that dermal glands are found in the Ampeliscidae on most of the appendages, and in the Talitridae scattered all over the body. Claus (I879) found unicellular glands scattered all over the body of Phronima. Holmes (I9OI) and Skutch (I926) both describe glands in the first and second peraeopods of two tubicolous species of Amphithöe, and have observed a silken thread emerging from a pore in the tip of the claw. Neither of them describe any dermal glands in other parts of the body.

The glands in the peraeopods of Leptocheirus pilosus are shown very well when stained in haematoxylin, and cleared (Fig. I $a$ ). The two main glands are in the basal (Ist) joint, running its whole length, one on each side of the muscle. There is also a smaller one behind these two. They join together distally and pass through the ischial (2nd) joint, where they are

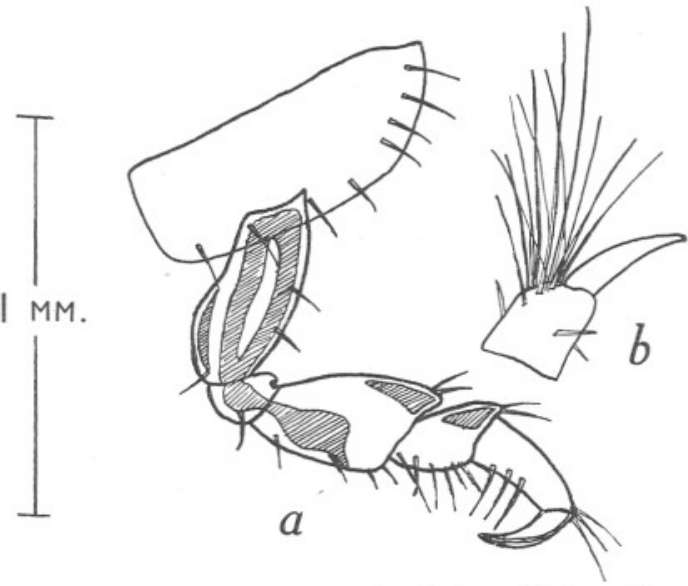
slightly expanded, into the Fig. I. a, Second peraeopod of Leptocheirus pilosus; meral (3rd) joint in whose glandular tissue shaded. b, Distal end of palmar proximal end they are again

expanded. Besides these there are two smaller pieces of glandular tissue in the distally dilated ends of the meral (3rd) and carpal (4th) joints. All these glands connect (probably by some sort of a duct, though none can be seen) with the canal which runs along the upper edge of the claw, to open at a pore in its truncated tip.

Besides these glands in the first and second pairs of peraeopods, dermal glands are found scattered over the body, being especially numerous on the coxal plates. These glands probably secrete a mucus cement in the same way as do the similar glands in the Talitridae.

\section{The Construction of the Tube}

Three different types of amphipod tube have been described, and that of Leptocheirus pilosus belongs to a fourth.

The first type is the Sand Burrow, and the least specialized sand burrows are built by members of the family Talitridae. These have dermal mucus glands scattered all over their bodies and as the animal burrows, the sand grains lining the burrow are probably smeared by this mucus, and hence stick together, preventing the walls of the burrow from caving in. Reid (I938) has described the digging habits of Talorchestia deshayesii (Audouin), 
and in this species at any rate the burrow is not permanent, but is filled up immediately behind the animal. Hence the mucus secreted on to the sides of the burrow can never harden into a permanent cemented wall.

Hunt (1925) gives a brief account of the tube of Ampelisca, which is of rather a more permanent nature. The animal burrows into the sand, and curls up just below the surface, with the head and antennae projecting out of the entrance. A cement is secreted from the dermal glands, which are on all the legs, and this becomes mixed with the grains on the inside of the burrow, eventually hardening into a purse-like tube in which the animal lives. No form of silk is produced and indeed it would scarcely be possible for the sand grains to be bound up by a silken thread. A similar type of semi-permanent sand burrow has been described in Microprotopus maculatus Norman by Schellenberg (1929). These tubes are still burrows, being supported on all sides by the surrounding sand.

The second type is the Mud Burrow, as described by Hart (1930) in Corophium volutator Pallas. The wall of the $\mathrm{U}$-shaped burrow is strengthened and prevented from falling in by a secretion of mucus from the glands, which is mixed with the mud as the animal burrows through it. This ultimately hardens. Here again no silken thread was observed. This burrow is semipermanent and is kept open while it is inhabited. Hart also notes that under some circumstances Corophium volutator can build a clumsy and fragile tube of mud and algal fragments, instead of the more usual burrow below the surface of the mud. In $C$. insidiosum I have noticed that a similar tube is the one normally used. This species does not appear to burrow.

The third type is a true tube built of comparatively large pieces of material, dead vegetation, living algal filaments and small stones, all bound together by strands of the so-called "amphipod silk". This type of nest was found in two species of Amphithöe by Holmes (I90I) and Skutch (1926), and is probably the most highly specialized. The only cement glands are those in the first and second pairs of peraeopods, and from the pores in the claws of these legs is spun a definite silken thread, which is fixed to the nest-building materials while still adhesive, later hardening. The finished nest consists of a bundle of algal filaments, etc., bound together by silk, down the middle of which runs the cylindrical tube lined by a silken web.

The tube of Leptocheirus pilosus belongs to a fourth type, and, as far as specialization is concerned, lies between those of Corophium and Amphithöe. Leptocheirus pilosus belongs to a family which is probably related to the Amphithoidae, though its members are in general not so specialized for a tubicolous existence.

This tube is a flat blister-like capsule fixed to the smooth surface of the thallus of Chondrus crispus, or to the upper sides of smooth stones. If the animal is kept in a glass vessel it will build its tube against the glass. The capsule is slightly longer than the animal which lives in it and rather more than half as broad as long. It is open at both ends, and the area of the mouth 
is considerably less than that of a cross-section through the tube in the middle, leaving an exit just large enough to allow the animal to get out. The wall of the tube is built of microscopic particles of detritus, mud and sometimes a very few short lengths of red or green algal filaments seldom more than five cells long. These are all cemented together into a relatively tough, thin and flexible wall fixed to the surface by its edges. The inner wall of the tube is formed by the bare surface against which it is built, and there is no lining of mud on this side. Thus if the tube is built against a piece of glass, the animal in the tube can be observed under natural conditions through the glass, which would not be possible with any of the other amphipods which have been examined. There is no question of a tube of long algal filaments bound together by "amphipod silk", as is found in Amphithöe.

When Leptocheirus pilosus is put into a vessel containing some of the detritus from the bottom of its pond, it will swim about for five minutes or so immediately above the bottom, trailing its last three pairs of peraeopods in the mud. Detritus becomes entangled in the long hairs on the distal ends of the palmar ( 5 th) joints of these limbs (Fig. I $b$ ), and is probably mixed with mucus, which covers the body. It is not, however, secreted from any pore in the claws of these posterior peraeopods. Soon the animal has a short trail of particles, perhaps a millimetre long, attached to these setae. It then settles down, usually in an angle of the dish where the mud lies thickest, and clears a patch for itself by the powerful beating of the pleopods. Next it lies on its side and begins to build the tube, starting with the trails of mud that have been collected on the posterior peraeopods. These are manipulated by the two anterior pairs of peraeopods and also by the gnathopods, and are fixed to the glass by a mucus cement secreted from the pore at the tip of the claw. No silken thread can be seen emerging from this pore, as in Amphithöe.

While building the nest the animal frequently turns through $180^{\circ}$ to face the other way and goes on building on the other side, until soon it lies within a belt of mud particles cemented loosely together, and fixed above and below its body to the glass. Meanwhile the pleopods are beating strongly in metachronal rhythm, creating a steady current. The flow is from head to telson below the body of the animal, down the space enclosed on either side by the deep coxal plates which are further apart than in most amphipods.

Any particles of suspended detritus near the head of the animal are drawn in under its body and caught in the sieve setae on the second gnathopod, in the same way as is the food, as described further on. These particles are combed off by the claw and palmar joint of the same gnathopod and are worked into the incipient tube by the first and second peraeopods. The animal is continually somersaulting round to face in the opposite direction, and the particles caught are thus packed on to the tube at each end alternately. This packing is done by the first and second pairs of peraeopods which are especially adapted for the secretion of cement from their hollow claws. Since 
the particles are worked by these claws, they will be well covered with cement which later hardens, sticking them together.

Under natural conditions the water in the pond is not still, either flowing out rapidly through the sluice, or on the flood tide, coming into the pond from the river at the other end, or leaking back through the faulty sluice gates. It therefore carries a considerable amount of suspended matter which would normally soon sink to the bottom, and hence there is an adequate supply of suitable building material in the water flowing over the Chondrus plants which grow, several inches above the bottom, on the stone walls leading up to the sluice gates. It is here that Leptocheirus pilosus lives and builds its nests. It will not live in foul black mud and does not build its nest on the undersides of stones lying in the mud, neither does it burrow.

The time required to complete the tube depends on the amount of building material available. With an adequate supply it is usually finished in about half an hour.

A newly made tube is comparatively loose and fragile, especially on the outside, where the particles of detritus are not firmly cemented together. More suspended particles are continually sieved out of the respiratory stream by the setae on the second pair of gnathopods, and these, together with the faeces, are worked into the wall from the inside by the anterior peraeopods. More cement is all the time being secreted on to the lining of the tube, both from the peraeopods, and from the dermal glands in the coxal plates which are in contact with different parts of the tube whenever the animal changes its position. The loose outer layer is soon washed away by the stream which, at some states of the tide, flows rapidly over it. Thus the finished tube, which may take a day or two to build, consists of the lining of the original one, composed of small particles of mud, tightly packed and cemented together into a tough and flexible wall well able to withstand the ebb tide which may flow over it with considerable force. It is not called upon to survive wave action.

This tube may be compared to the lining of the burrow of Ampelisca or Corophium, which is above the surface of, and not supported by the surrounding mud or sand. It is stronger than the lining of a burrow, though still composed of mud particles packed and cemented together by the dermal glands. No silken web is developed and for this reason the tube is more primitive than that of Amphithöe.

A series of experiments was conducted to find what use was made of different building materials. Four types were investigated.

(I) Natural detritus. The tubes were built in under half an hour.

(2) Detritus dried by combustion. As above.

(3) Ulva thalli. Where a large piece was provided the animals would, after several hours, come to rest in the wrinkles on the surface. Where there were many small shreds of one square millimetre or so, they would be collected together in a corner of the dish, the animal lying underneath the 
pile. After a day or more some of the pieces are very loosely bound together in a thin mucus film.

(4) Silver sand. The specimens, after several hours, settle down on the sand and loosely cover themselves with grains. After a day the sand grains cohere very loosely, and if the "tube" is detached from the glass it can be towed about in the water by a pair of forceps without coming to pieces. It will not support its own weight out of the water. When examined under the microscope the sand grains are seen to be held together on a net of very fine, irregular and anastomosing threads. These are probably secreted from the claw ducts on the Ist and 2nd peraeopods alone, and the fragility of the structure is due to the fact that the grains are too large to be cemented together by the secretions from the coxal plates.

If the first and second pairs of peraeopods are removed from an animal it will live for several days, but is unable to build a tube. The glands on these legs are therefore essential for the building of the tube, and the first loose covering is probably cemented by mucus from these alone. Only at a later stage, in the formation of the tough permanent wall, are all the cement glands used to bind all the particles firmly together. As a control, some specimens were observed, from which the fourth and fifth pairs of peraeopods, which carry no cement glands, had been removed. These were able to construct normal tubes, and it follows that the shock of removing four legs would not be sufficient to account for the inability of the specimens in the previous experiment to build their tubes.

\section{Position IN THE TUBE}

If the bottom of a glass dish is covered with microscope cover-slips, and the dish is then filled with muddy water and a number of Leptocheirus pilosus, the animals will soon have built their nests on the cover-slips which may then be turned over, the four corners being supported with plasticine. The animal can now be observed in its tube under conditions which are much more natural than would be possible with most other tubicolous amphipods, which surround themselves with complete cylindrical walls of opaque materials.

L. pilosus lies with its head just inside the mouth of the tube, with the antennules waving about in the water outside. The antennae are generally held motionless, and pointing downwards. In the female the meral and carpal joints of the first gnathopod are horizontal, and at right angles to the first two joints. The gnathopods are small, and are not crossed. They are in constant movement and help to convey food to the maxillipeds and thence to the mouth. Even when there is no food, the claw is continually opening and shutting. The first gnathopods of the male, which are very long, are tightly crossed under the head (Fig. 3). The palm often projects just out of the mouth of the tube while the limb is practically still. The claw and palm are too far from the mouth to be of any assistance in feeding. They are indeed 
a hindrance to the animal when changing its position in the tube, and I know of no other genus of Amphipoda which carry their gnathopods in this way. No suggestion is put forward to explain the reason, if any, for this position. In other respects the position in the tube is the same for both sexes (Fig. 2). The body is arched, the mesosome being above the head, while the urosome is held vertically downwards, with the uropods touching the floor of the tube. The peduncle of the first pair of uropods is at an angle to the others, and its rami point forwards. The first two pairs of peraeopods have their claws and carpal joints resting on the floor of the tube, and are never at rest, always

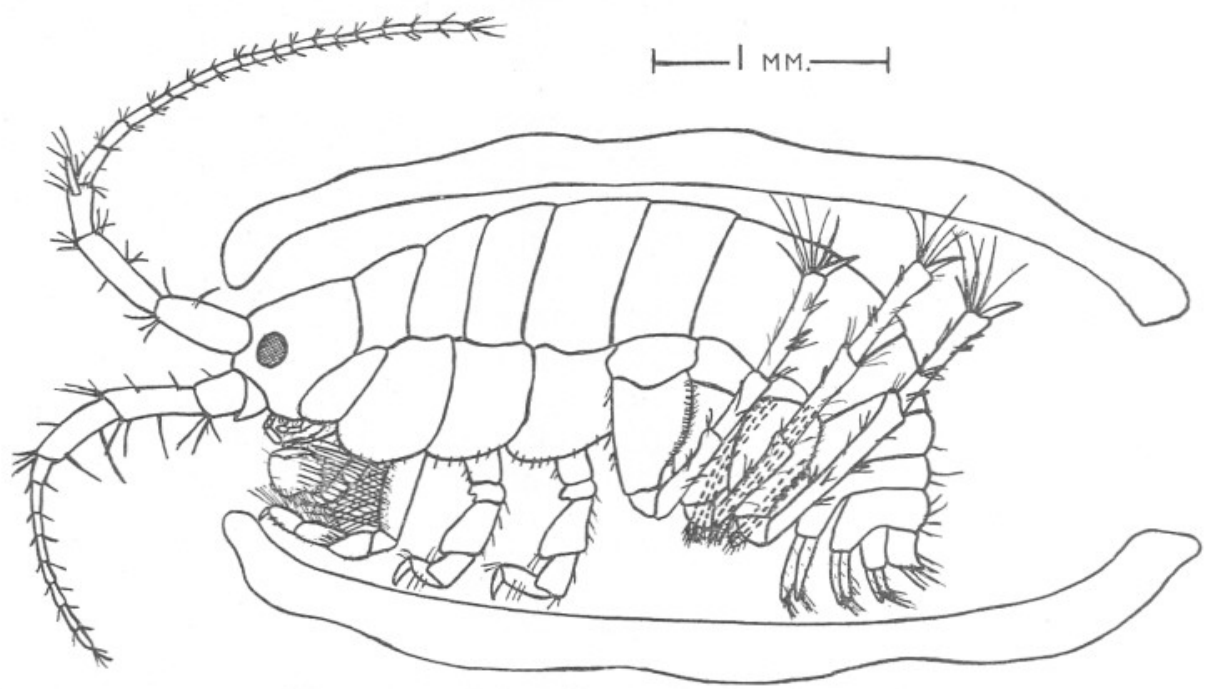

Fig. 2. Leptocheirus pilosus ô. Position in the tube.

stamping at it. The second gnathopod has its first two joints vertical, with the remainder horizontal. Its position is more fully described below. The last three pairs of peraeopods are bent back over the metasome, in the position characteristic of so many other amphipods, with their claws hooked into the wall of the tube. About once every thirty seconds, or as often as the animal is alarmed, the metasome is still further arched, withdrawing the head, while the peraeopods push against the tube, causing the animal to turn a neat backwards somersault so that its head appears at the other entrance. The same reversal of position has been described in Amphithöe.

\section{FEEDING HaBits}

Hart (1930) and others have recognized three types of amphipod feeding:

(I) Biting, e.g. Talitrus, Lysianassa, Amphithöe, etc.

(2) Selective deposit feeding, e.g. Corophium.

(3) Filter feeding, e.g. Haustoriidae. 
Leptocheirus pilosus belongs to the second class. Its mouthparts are in all essentials similar to the biting mouthparts of Amphithöe. The mandibles have molar processes, and the other parts do not have the specialized fringes of pinnate setae described by Dennell (1933) in Haustorius arenarius which is a true filter feeder. Any feeding current is not produced by the mouthparts. A stream of water is, however, induced to flow from the head to the telson by the beating of the pleopods. Since the animal is in a tube, the water cannot flow in at the sides and a strong current through the entrance is thus produced. Any solid particles are sieved (this is a better word than filtered) out of the stream by a special arrangement of setae on the second gnathopod.

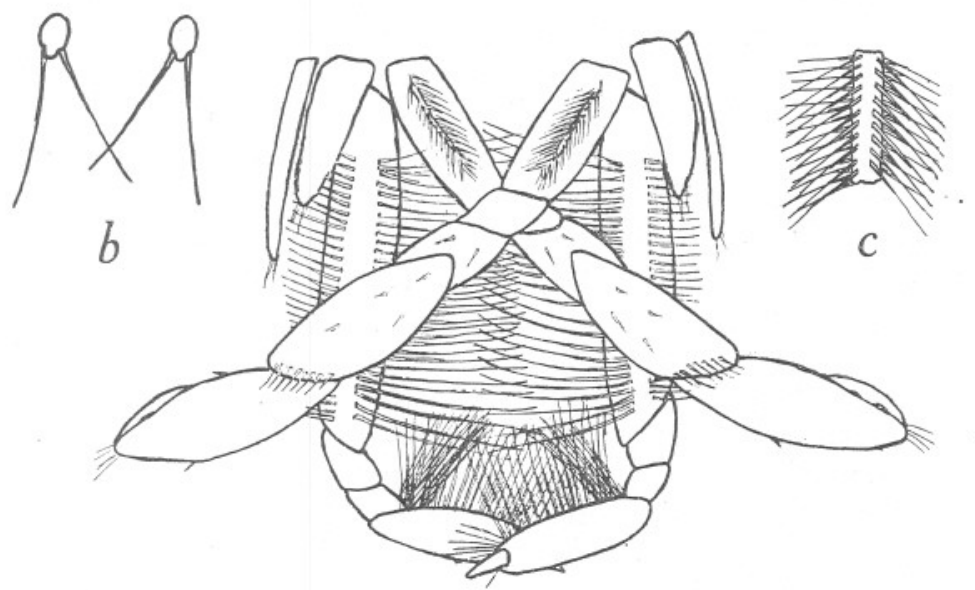

$a$

Fig. 3. Leptocheirus pilosus $\hat{\text { o. }} a$, First and second gnathopods in their normal positions seen from in front, to show the arrangement of sieve setae. $b$, Diagram of a transverse section through the basal joint of the second pair of gnathopods, showing the two rows of sieve setae. c, Part of a sieve seta. Magnified.

On the anterior face of the basal (Ist) joint of this limb there are two rows of very long feathery setae. The outer row is parallel with the walls of the tube, while the inner points inwards at an angle of about $30^{\circ}$ (Fig. $3 \mathrm{~b}$ ). The ends of the setae of this inner row cross in the middle with those on the opposite gnathopod forming a fine sieve through which the stream flowing down the tube must pass. There are single rows of similar setae projecting upwards and inwards from the horizontal meral and carpal joints, and there is thus an enclosed space behind the first pair of gnathopods and under the mouth. This is closed posteriorly by the two inner rows on the basal joints, laterally by the outer rows on these joints, and dorsally and ventrally by the head, and setae of the meral and carpal joints respectively. Any solid suspended matter in the food stream is caught in this space. Periodically the second gnathopod is bent at the ischial joint, and the distal segments are lifted up into the space 
between the two rows of setae on the basipodite. Any particles caught in these setae are combed off into the enclosed space by those on the distal joints of the limb. The detritus in this space is turned over by the maxillipeds, assisted by the first pair of gnathopods in the female, and any suitable particles are transferred to the mouth. This method of food collection, for which the term sieve feeding is proposed, is quite different from the filter feeding of Haustorius arenarius and many other animals. In the latter, water having various food particles in suspension is drawn through the mouth appendages, which are highly specialized, both creating the feeding current and performing the filtration. In the sieve feeder the creation of the feeding current and the extraction of food particles from it are performed by appendages other than those of the head, and the food materials so collected are offered to the mouthparts as a loosely concentrated mass of detritus, in much the same state as is the food of any other selective deposit feeder. The mouthparts are in no way specialized for filter feeding and a sieve feeder, such as Leptocheirus could not be classed with Haustorius, but rather with Corophium and the other selective deposit feeders.

Besides sieve feeding Leptocheirus pilosus can also behave as a normal selective deposit feeder. If any large mass of detritus is perceived near the mouth of the tube by the sensory antennules, the animal will partially emerge from the tube, grasp at it with the antennae, which have long and stout setae on the ventral sides of the peduncular joints, and draw it into the mouth of the tube. In neither sex are the gnathopods used to grab at food, as in Amphithöe. This method of collecting food was often seen in animals in the tubes on the bottom of a glass dish, where there was plenty of detritus lying round the nest. It is probably used by the occupants of nests on flat stones near the bottom of the pond, but when the tubes are on Chondrus crispus some distance above the bottom, large masses of food which could be taken in by the antennae would not be common, and it is probable that the sieve method is then the most usual.

Leptocheirus pilosus never gnaws at such algae as Ulva or Enteromorpha, as does Amphithöe. It will die if it is put in a dish containing nothing but such an alga. The contents of the gut consist entirely of very small particles, diatoms and very small lengths of algal filaments being recognizable.

The feeding habits of Leptocheirus pilosus are thus entirely different from those observed by Holmes and Skutch for Amphithöe, which has no adaptations for sieve feeding, and is often carnivorous. Hart describes a very much more simplified form of sieve feeding in Corophium volutator, which possesses a single row of setae on the distal joints of the first pair of gnathopods; but Corophium is primarily a true selective deposit feeder, and does not use these setae to any great extent.

Most of the material which enters the space in front of the sieve setae is not used as food. Part of it is worked into the walls of the tube by the first and second peraeopods. The rest is left behind when the animal somersaults 
round, and is then kicked out of the entrance of the tube by the urosome, which appears at this end. No solid particles are allowed to get past the second gnathopods, and so the tube is kept clear of particles which might, in very dirty water, block it up. The faeces are disposed of in the same way.

The tubes on the Chondrus fronds are exposed for several hours at each tide. The animals remain in them, and water is held in the tube by capillarity. When thus exposed the pleopods beat gently, keeping up a circulation of the water in the nest, which is thus able to aerate the branchial lamellae with the oxygen which presumably diffuses into the water at each end of the tube. The antennae and antennules are withdrawn, and the animal no longer performs its frequent changes of position. If it is removed from its tube when out of the water it is not able to break the surface film when the Chondrus plant is reimmersed. Under natural conditions however, it remains in its tube, and is thus never out of water.

Leptocheirus pilosus is able to swim quite efficiently, unlike Amphithöe which, if removed from its nest, will lie on the bottom, grasping at any solid object which is there. Leptocheirus pilosus will usually, however, enter a vacant tube, or build a new one as soon as possible. It may eject another individual from its tube, if it can enter the tube from behind before the occupant has time to reverse its position and face the intruder. If it can get in from behind, the rightful owner is easily pushed out. It cannot, however, be ejected if it is facing the intruder. L. pilosus will seldom leave its tube spontaneously, though a few individuals can be caught if a net is drawn gently over the Chondrus plants. Since any disturbance causes the animal to retreat further into its tube, these few must probably have been swimming about freely.

\section{BREEDING Habits AND Life History}

No attempt to go very deeply into this question was made, and further work on the breeding habits of amphipods in general is contemplated. In the meantime the few observations which were made may be recorded.

Ovigerous females were obtained from the beginning of April till September inclusive. These on the average carried eleven eggs each, and very few individuals were found with more or less than this number. The number is just half that given by Chevreux, but this may be due to climatic or other factors.

There was a great preponderance of females over males during the whole time the species was under observation, and the relative numbers did not appear to fluctuate much. A collection of fifty-eight made in August contained seven males and thirty-six females, with fifteen too young for their sex to be recognized.

Two adult individuals were never observed together in one nest, and indeed there would not be enough room in any ordinary one. According to Skutch a male and female Amphithöe rubricata are often found together. Only one copulating pair was observed, and this was outside the nest. It was 
examined under a hand lens, and the male seemed to be holding his mate with the second gnathopods and anterior peraeopods. The first gnathopods were crossed under the body in the usual position, and were not used in the clasp. The peculiar carriage of these limbs does not seem to be explicable as a clasping adaptation. The pair separated when being transferred to another dish for further observation under the microscope, and this would seem to cast some doubt on whether they were really copulating, since the clasp is usually extremely tenacious.

In some species of Amphipoda, Haustorius arenarius investigated by Dennell (1933) and Corophium bonelli, by Crawford (1937) and a few others, the male is unknown, and reproduction is presumably parthenogenetic. No experiments were undertaken to determine whether this was so with Leptocheirus pilosus, either as a general rule or occasionally, but the single and rather doubtful observation of a copulating pair, together with the disproportionate sex ratio suggest that parthenogenesis may occur. In most amphipods clasping pairs are very noticeable throughout the breeding season.

As in most species the young remain in the brood pouch until after the first moult, while they remain in the tube of the mother until the second, and possibly later. On leaving they soon construct their own tubes. Moulting is normal, the animal emerging from a dorsal crack just behind the head and leaving the old skin otherwise unbroken. The moult always occurs outside a tube, and if the animal has grown during the process it probably builds a completely new tube.

\section{CONCLUSION}

In its general behaviour Leptocheirus pilosus occupies a position between Corophium volutator and Amphithöe rubricata. It is able to swim efficiently, unlike $A$. rubricata, but it appears that it does not habitually leave the nest, as does Corophium volutator. The nest is a true one, not a mere burrow in the mud, but in its cementing it resembles the burrow of $C$. volutator. The secretion of silken threads for the construction of the nest is not found, and the cement glands are not confined to the first two peraeopods, as in Amphithöe rubricata.

The sieve-feeding mechanism is an interesting adaptation to the tubicolous existence, which does not appear previously to have been recorded in the Amphipoda. In this respect Leptocheirus pilosus is probably more highly specialized than are the other tube-building forms. Amphithöe has both pairs of gnathopods grasping and subequal, and seizes the food with them in the same way as do such free swimming genera as Gammarus. It must partly emerge from its tube in order to grasp at passing food masses, and has no means of feeding while it is inside the tube. Corophium volutator has a single row of primitive sieving setae on the posterior border of its first gnathopod, which are analogous to the double row on the anterior border of the second gnathopod of Leptocheirus pilosus. It obtains its food more frequently, how- 
ever, in the normal manner of other detritus feeders, and its sieving mechanism is not so highly developed as that of Leptocheirus pilosus.

This sieve feeding is analogous to the true filter feeding of Haustorius arenarius (Dennell, I933), and the mysids. In these the collection of food particles, and creation of the food current, are both performed by specialized mouthparts, while in Leptocheirus pilosus this is done by the appendages of the meso- and metasome, and the mouthparts are of the unspecialized biting type. Since the animal lives in a tube, the current produced by the pleopods is bound to flow down the tube and over the sieving setae; it cannot get in at the sides, nor from underneath behind the second gnathopod, as would happen if there were no tube. It can therefore do its sieving on a larger scale than can the mysids or Haustorius arenarius, whose food current is of a much smaller capacity, and is produced by the mouthparts in an enclosed space which, since there is no tube, can only be provided by a fold of the carapace, or by the walls of pinnate setae through which water cannot easily pass. No comments will be made on the breeding habits of Leptocheirus pilosus until further experimental evidence has been obtained.

I wish to express my thanks to Mr D. M. Reid, for his valued help and criticism of this work.

\section{SUMMARY}

A study made of the adaptations to tubicolous life found in the small brackish water Photid Amphipod, Leptocheirus pilosus Zaddach, revealed several interesting points.

The presence of cement glands in many amphipods has been recognized by several previous authors. In L. pilosus these glands are found mainly in the upper joints of the first two pairs of peraeopods, opening to the exterior through a common duct in the claw. Unicellular glands are also found all over the body, particularly on the coxal plates.

The tubes of amphipods are of four main types:

(I) Sand burrow, e.g. Talitridae, Ampelisca.

(2) Mud burrow, e.g. Corophium volutator.

(3) Homogeneous leathery tube, e.g. Leptocheirus pilosus.

(4) Nest of algal fragments, bound together by "amphipod silk", e.g. Amphithöe rubricata and A. longimana.

The third type has not previously been described. It consists of a short, flat blister-like capsule fixed to a flat surface, usually the alga Chondrus crispus, and is built of minute particles of detritus cemented firmly together with a secretion from the dermal glands. Experiments showed that Leptocheirus pilosus could rapidly make a normal tube, both from natural and combusted detritus. If supplied only with fragments of Ulva, or sand grains, a very fragile tube was eventually constructed, the parts being fixed together by weak strands of mucus. No "amphipod silk" was used. An animal from 
which the Ist and 2nd pairs of gland-bearing peraeopods have been removed is unable to build a tube.

Leptocheirus pilosus collects its food by the method of sieving. A stream of water, created by the pleopods, flows down the tube and any solid particles suspended in it are collected by an arrangement of long setae on the second pair of gnathopods. From the mass of detritus thus collected, suitable food particles are selected by the mouthparts. The remainder is incorporated into the wall of the tube from the inside. This method of feeding is of the selective deposit type, and does not resemble the filter feeding found in some species. The animal is able also to draw into the tube masses of detritus with the antennae, but it does not gnaw at large pieces of an alga, nor is it carnivorous.

From the scanty observations made, the breeding habits of the species do not appear to be normal. There is a great preponderance of females and the occurrence of copulation is doubtful. The peculiar carriage of the well developed first pair of gnathopods by the male does not appear to be an adaptation for pairing, and no explanation for it is put forward. It is tentatively suggested that the species may be parthenogenetic.

The young remain in the mother's brood pouch until after the first moult, and remain in her tube for some time after this. On leaving it they forthwith build tubes of their own.

\section{REFERENCES}

Calman, W. T., 1909. Crustacea; in A Treatise on Zoology, ed. Sir R. Lankester, 7 Appendiculata 3rd Fasc., pp. 235-6. London.

Chevreux, E. \& Fage, L., I925. Faune de France, Vol. 9. Amphipodes, pp. 322-3.

Claus, C., I879. Der Organismus der Phronimiden. Arbeit Zool. Instit. Wien, Bd. II, pp. $59-88$.

Crawford, G. I., I937. A review of the amphipod genus Corophium, with notes on the British species. Fourn. Mar. Biol. Assoc., Vol. xxi, pp. 589-630.

Dennell, R., I933. The habits and feeding mechanism of the amphipod Haustorius arenarius Slabber. Fourn. Linn. Soc. Zool. London, Vol. xxxvIII, pp. 363-88.

HART, T. J., I930. Preliminary notes on the bionomics of the amphipod Corophium volutator Pallas. Fourn. Mar. Biol. Assoc., Vol. xvi, pp. 76I-89.

Holmes, S. J., I90I. Observations on the habits and natural history of Amphithöe longimana Smith. Biol. Bull., Vol. II, pp. 165-93.

Hunt, O. D., I925. The food of the bottom fauna of the Plymouth fishing grounds. Fourn. Mar. Biol. Assoc., Vol. xiII, pp. 560-99.

ReID, D. M., I938. Burrowing methods of Talorchestia deshayesii Audouin. Ann. Mag. Nat. Hist., Ser. I I, Vol. I, pp. I55-7.

SChellenberg, A., 1929. Körperbau und Grabweise einiger Amphipoden. Zool. Anz., Leipzig, Bd. Lxxxv, pp. I86-90.

Sexton, E. W., I9I I. On the amphipod genus Leptocheirus. Proc. Zool. Soc. London, pp. 56I-94.

SkUTCH, A. F., 1926. On the habits and ecology of the tube-building amphipod Amphithöe rubricata Montagu. Ecology, Brooklyn, N.Y., Vol. vII, pp. 48I-502. 
SMrth, S. J., I874. Tube building Amphipoda. Amer. Fourn. Sci., Ser. 3, Vol. vir, p. $60 \mathrm{I}$.

- 1882. On the amphipodous genera Cerapus, Unciola and Lepidactylis. Trans. Conn. Acad. Arts Sci., Vol. Iv, pp. 268-84.

Stebbing, T. R. R., I906. Amphipoda I. Gammaridea. Das Tierreich, Vol. xxi. Berlin.

Stephensen, K., I929. Die Tierwelt der Nord-und Ost-See, Bd. xIv, x, f. Amphipoda, pp. I3, I59.

ZAvATTARI, E., I920. Osservazioni etologiche sopra 1' anfipodo tubicolo Ericthonius brasiliensis Dana. R. Comm. Talassogr. Ital., Mem. I42. Venezia. Ferrari 8 ${ }^{\circ}$, p. 22. 